\title{
Richard Hooker's Doctrine of Royal Supremacy in the Church of England
}

\author{
A. A. Palamarchuk, I. A. Fadeyev
}

For citation: Palamarchuk A. A., Fadeyev I. A. Richard Hooker's Doctrine of Royal Supremacy in the Church of England. Vestnik of Saint Petersburg University. History, 2018, vol. 63, issue 1, pp. 158-173. https://doi.org/10.21638/11701/spbu02.2018.111

The article deals with the doctrine of Royal Supremacy in the Church of England as formulated by Richard Hooker (March 1554 - 3 November 1600) in his opus magnum 'Of the Laws of the Ecclesiastical Polity'. An attempt is made not only to describe the basic tenets of the doctrine, but also to identify the sources used by its author. It's demonstrated that there's an essential link between Richard Hooker's soteriological and ecclesiological teachings, on the one hand, and his vision of the state-church relations in England, on the other hand. The Royal Supremacy remains a major element in the structure lying at the heart of identity of the Church of England. The connections between the English monarch and the English church emerged during the Anglo-Saxon period of the British history and were developed throughout the Middle Ages. They survived a turbulent century of reformations and took new shape and acquired new foundations without having lost the former ones. The authors also show that Richard Hooker's doctrine of Royal Supremacy was heavily influenced by the legal tradition of civil law, formulated by Bartolo da Sassoferrato (1313 - 13 June 1357) and Henry de Bracton (c. 1210 - c. 1268), which was instrumental in assuring a degree of continuity with the medieval legal thinking on royal patrimonial dominion over a national church as well as in creating an essential link between that intellectual tradition of civil lawyers and the $16^{\text {th }}$ century theological apologies of the Divine Right of kings. The Hookerian doctrine is reviewed against a particular historical background embodied in one of the fruits of the Elizabethan religious settlement, namely, the tradition of ecclesiastical conformism, which was widely held throughout the reformed English Church in the late $16^{\text {th }}-$ early $17^{\text {th }}$ century. Contrasting the former with the latter serves the purpose of demonstrating Richard Hooker's innovative approach to the doctrine in question.

Keywords: Church of England, Royal Supremacy, Richard Hooker, Of the Laws of Ecclesiastical Polity, civil law.

Palamarchuk Anastasia A. - PhD in History, Senior Lecturer, St. Petersburg State University, Universitetskaya nab., 7-9, St. Petersburg, 199034, Russian Federation; a.palamarchuk@spbu.ru

Fadeyev Ivan A. - MA, M. V. Lomonosov Moscow State University, Lomonosovsky pr., 27-4, Moscow, 119192, Russian Federation; fadeyev.ivan@yahoo.co.uk

Паламарчук Анастасия Андреевна - д-р ист. наук, старший преподаватель, Санкт-Петербургский государственный университет, Российская Федерация, 199034, Санкт-Петербург, Университетская наб., 7-9; a.palamarchuk@spbu.ru

Фадеев Иван Андреевич - магистр, Московский государственный университет им. М. В. Ломоносова, Российская Федерация, 119192, Москва, Ломоносовский пр., 27, корп. 4; fadeyev.ivan@yahoo.co.uk

(c) Санкт-Петербургский государственный университет, 2018 


\section{Учение Ричарда Хукера о королевской супрематии в церкви Англии}

\section{А.А. Паламарчук, И. А.Фадеев}

Для цитирования: Palamarchuk A. A., Fadeyev I. A. Richard Hooker's Doctrine of Royal Supremacy in the Church of England // Вестник Санкт-Петербургского университета. История. 2018. Т. 63. Вып. 1. С. 158-173. https://doi.org/10.21638/11701/spbu02.2018.111

Статья посвящена учению о королевской супрематии в церкви Англии, сформулированной в основном труде Ричарда Хукера (март $1554-3$ ноября 1600 гг.) «О законах церковного устройства». В статье предпринята попытка не только дать описание основных положений данного учения, но и идентифицировать источники, на которые опирался его автор. Демонстрируется важная связь между сотериологическими и экклесиологическими воззрениями Ричарда Хукера, с одной стороны, и его представлениями о государственно-церковных отношениях в Англии - с другой. Авторы также показывают, что его учение о королевской супрематии испытывало высокую степень влияния юридической традиции цивильного права, представленной, в частности, Бартоло де Сассоферато (1313 - 13 июля 1357) и Генри де Брактоном (ок. 1210 ок. 1268 гг.), которая послужила важным инструментом в создании как определенной степени преемственности со средневековыми юридическими представлениями о королевской патримональной власти над национальной церковью, так и связи между этой интеллектуальной традицией юристов цивильного права и богословскими апологиями божественного права королей XVI в. Хукеровское учение рассматривается на фоне сложившейся в результате Елизаветинского религиозного устроения «традиции» церковного конформизма, которая была широко распространена в реформированной Английской церкви конца XVI - начала XVII в. Контраст между учением Ричарда Хукера и конформистской традицией позволяет продемонстрировать новаторство его подхода к обсуждаемому вопросу.

Ключевые слова: церковь Англии, королевская супрематия, Ричард Хукер, О законах церковного устройства, цивильное право.

The history of the English Reformation represents a complex phenomenon within which politics, philosophy, and religion are closely intertwined. The struggle between various factions at the royal court and within the Church of England in the $16^{\text {th }}-17^{\text {th }}$ centuries posed thorny problems for English monarchs and prelates of the English Church, which required collaborative actions. The movement of the English "puritans" 1, who, even at the time of Edward VI, strived for radical transformations of the political and ecclesiastical life of the nation, challenged and threatened the regal power of Elizabeth I and James I Stuart as well as the traditional structure of the Church of England. The article will not only attempt to outline the major principles of Richard Hooker's doctrine of Royal Supremacy, but also identify the sources he based them on. The theme is of particular relevance for the issue of the self-identification of the Church of England, and, consequently, for the Anglican identity ${ }^{2}$.

${ }^{1}$ Given the ambiguity of the term, it will be used with the quotation marks in this article. For the problematic usage of the term Puritan and its criticism, see: Clary I. H. Hot Protestants: A Taxonomy of English Puritanism // Puritan Reformed Journal. 2010. N 2-1. P.41-66.

${ }^{2}$ Davydov I. P., Fadeyev I. A. (Etno)Religioznaia identichnost': metodologicheskie aspekty klassifikatsii. Iugra, Sibir', Rossiia: politicheskie, ekonomicheskie, sotsiokul'turnye aspekty proshlogo i nastoiashchego. Nizhnevartovsk, 2016. P. 14. 
Elizabeth I, as well as James I, disapproved of Calvinism and its supporters, "puritans", both due to creedal rigorism of the latter and owing to purely political reasons: "puritan" perceptions (having a pronounced judicial nature) of the absolute authority of the Scripture in spiritual issues and in the issues related to the structure and governance of the state and the Church meant the monarch's submission to the collective will of the Church in Calvinistic terms, and conflicted with the doctrine of the divine right of kings and Royal Supremacy, which played a crucial role in the history of the relationships between the Crown and the Church in England 3 . "Puritans", who insisted on Presbyterian clerical polity and indisputable authority of the Bible, regarded the remaining episcopal structure of the Church of England, the Book of Common Prayer, and Thirty-Nine Articles as the signs of unextirpated "Papism"4, which caused their attacks against the latter.

It was an English theologian Richard Hooker who was privileged to become an apologist of the Church of England and the so-called Elizabethan Settlement. His sermons and work "Of the Laws of Ecclesiastical Polity" made him an English religious philosopher par excellence, the founder of the systematic approach to theology in the Church of England ${ }^{5}$, who determined the development of the theological tradition within this Church for centuries ahead ${ }^{6}$.

R. Hooker's thought is of fundamentally scholastic nature, and the structure of his principal work, despite some deviations, follows the structure of the major work by Thomas Aquinas: according to A. Nichols, eight volumes "Of the Laws of Ecclesiastical Polity" is a "creative variation" of the "Summa Theologicae"7. Similarly to St Thomas Aquinas, R. Hooker, being within the framework of the Augustinian theological paradigm, attempts at creatively synthetizing it with the intellectual legacy of Aristotle. R. Hooker also devotes scrupulous attention to the works by Greek Fathers of the Church. At the same time, a range of aspects in Hooker's theological system bear the signs of influence of Scotism and later scholasticism (Robert Bellarmine, Luis de Molina) rather than that of Thomism.

In order to adequately embrace and assess the substantive side of R. Hooker's ideas and their place in the intellectual tradition of the Church of England, it is necessary to outline the chief elements which he defended in his works, namely - the major characteristics of the Elizabethan Settlement. It is all the more so due to the fact described by the Archbishop of Canterbury, Michael Ramsey: "Anglican theology followed the Elizabethan Settlement, rather than the other way round. Distinctive Anglican theology began within the reign of the first Queen Elizabeth..."

${ }^{3}$ Nichols A. The Panther and the Hind. A Theological History of Anglicanism. Edinburgh, 1993. P. 17; Laski H. J. The Political Ideas of James I // Political Science Quarterly. 1919. Vol. 34 (2). P. 269.

${ }^{4}$ For the meaning of the term Papism, as well as the nature of the English Anti-Catholicism, see: Fadeyev I. A. Tserkov Anglii: problema konfessional'noi samoidentifikatsii v istoricheskoi perspective. Moscow, 2015. P. 82-83.

5 Gibbs L. Richard Hooker's Via Media Doctrine of Scripture and Tradition // Harvard Theological Review. 2002. Vol. 95 (2). P. 228; Avis P. Anglicanism and the Christian Church. London, 2002. P. 31.

${ }^{6}$ For terminological issue in the history of the Reformed Anglican Church see: Fadeyev I. A. Tserkov Anglii: problema konfessional'noi samoidentifikatsii $v$ istoricheskoi perspective. Moscow, 2015. P.78-151.

7 Nichols A. The Panther and the Hind. A Theological History of Anglicanism. P. 45.

8 Ramsey M. The Anglican Spirit. New York, 2004. P. 8. 


\section{The Elizabethan Settlement}

I. Judicially "The Elizabethan Settlement" realized itself in two Parliamentary Acts of 1558, The Act of Supremacy and the Act of Uniformity.

(1) The first Act granted the monarch the title of the Supreme Governor of the Church of England and claimed that "Jurisdictions Privileges Superiorities and Preheminences Spirituall and Ecclesiasticall ... shall for ever by aucthorite of this present Parliament be united and annexed to the Imperiall Crowne of this Realme"9. The doctrine of the divine right of kings retained its connection with the doctrine of Supremacy, and both doctrines turned out to be directly linked with the perceptions of the divinely instituted episcopacy thanks to R. Hooker and English theologians of the $17^{\text {th }}$ century ${ }^{10}$.

(2) The Act of Uniformity declared The Book of Common Prayer the only lawful directory and service-book, and any resorting to other liturgical books or protesting against the Book of Common Prayer was to be punished ${ }^{11}$.

II. The preservation of the episcopate and confirmation of the full ordinary power of bishops, who had to be consecrated by bishops and retained apostolic succession in their dioceses ${ }^{12}$.

III. Via media between the Roman Catholic Church and continental Reformation: thus, the doctrine of justification by grace and redemptive faith was accepted, but also a significant role was given to good works in the process of salvation, to the doctrine of election and predestination, although the Calvinist doctrine of double predestination was rejected ${ }^{13}$.

\section{Status quo of Elizabethan conformism}

The conformism of Elizabethan Church of England formed as a result of the Settlement can be defined by the following statements:

1. Erastian governance in the Church based on the doctrine of Royal Supremacy.

2. The justification of the episcopal polity by the doctrine of supremacy: the episcopate is instituted de jure humano, therefore, the issue of its preservation lies within adiaphora, i.e., consequently, it is related to the affairs of the Crown ${ }^{14}$.

3. The ecclesiastical rites and ceremonies also fall within the domain of adiaphora. As they are under the jurisdiction of the monarch, its acceptance is what is approved and installed by legitimate authorities. The primary purpose of the rites

${ }^{9}$ Act of Supremacy 1558, Section VIII. URL: http://www.legislation.gov.uk/aep/Eliz1/1/1 (accessed 10.05.2017)

${ }_{10}$ Nichols A. The Panther and the Hind. A Theological History of Anglicanism. P. 21-24, 51-52.

11 Documents Illustrative of English Church History / eds H. Gee, W. J Hardy. London, 1914. P. 459-461.

12 Podmore C. Aspects of Anglican Identity. London, 2005. P.3; Documents Illustrative of English Church History. P. 464, 465-466; Nichols A. The Panther and the Hind. A Theological History of Anglicanism. P. 37; Hurst J. F. The Elizabethan Settlement of the Church of England // The American Journal of Theology. 1899. Vol. 3 (4). P. 687.

${ }_{13}$ Ramsey M. The Anglican Spirit. P.7.

14 Lake P. The 'Anglican Moment'? Richard Hooker and the Ideological Watershed of the 1590s // Anglicanism and the Western Christian Tradition / ed. by S. Platten. Norwich, 2003. P. 91. 
and ceremonies is to explicitly demonstrate the obedience to the lawful power and to assist in maintaining order and uniformity ${ }^{15}$.

4. Elizabethan conformism, which had reflected status quo ante of the Church of England before R. Hooker radically transformed it, determined itself, according to P. Lake, by denying two extremities: on the one hand, Rome and Roman "Papism", and, on the other hand, radical forms of Reformation (before the second half of the $16^{\text {th }}$ century it was Anabaptism; afterwards - Puritanism), whose representatives opposed uniformity.

5. The dispute with Rome is central to understanding Elizabethan conformism as well as the specificity of the theological discourse in the Church of England: as a result of this dispute some of the doctrines and views a priori began to be associated with Rome, even when in reality they had nothing to do with its dogma. It brought about unavailability of some theological themes and approaches for conformist theologians in their confrontation with "puritans" as the reference to such themes on the part of the former inevitably made them open to accusations of "Papism"16. It resulted in painstaking care exercised by theologians of the $16^{\text {th }}-17^{\text {th }}$ centuries during the discussions of some major doctrinal issues, which could be observed in their works.

"Erastian" views of the English Reformation to a large extent were perceived within the frameworks of the concept of the relationship between the Crown and the Church which was realized in the Thirty-Nine Articles and distinguished works by R. Hooker. Article XXXVII Of the Civil Magistrates affirms:

The King's Majesty hath the chief power in this Realm of England, and other his Dominions, unto whom the chief Government of all Estates of this Realm, whether they be Ecclesiastical or Civil, in all causes doth appertain, and is not, nor ought to be, subject to any foreign Jurisdiction.

Where we attribute to the King's Majesty the chief government, by which Titles we understand the minds of some slanderous folks to be offended; we give not to our Princes the ministering either of God's Word, or of the Sacraments, the which thing the Injunctions also lately set forth by Elizabeth our Queen do most plainly testify; but that only prerogative, which we see to have been given always to all godly.

Princes in holy Scriptures by God himself; that is, that they should rule all estates and degrees committed to their charge by God, whether they be Ecclesiastical or Temporal, and restrain with the civil sword the stubborn and evil-doers.

The Bishop of Rome hath no jurisdiction in this Realm of England.

The Laws of the Realm may punish Christian men with death, for heinous and grievous offences.

It is lawful for Christian men, at the commandment of the Magistrate, to wear weapons, and serve in the wars ${ }^{17}$.

Richard Hooker, whose doctrine of Royal Supremacy continues to remain relevant to the theology of constitutional position of the Church of England even today ${ }^{18}$, stems from

15 Ibid. P. 92.

16 Ibid. P.93-94.

17 Articles of Religion // Book of Common Prayer. Cambridge, 2004. P. 627-628.

18 Percy M. Opportunity Knocks: Church, Nationhood and Establishment // The Established Church / eds M. Chapman, J. Maltby, W. Whyte. London, 2011. P 30. 
his soteriological paradigm: from the doctrine of grace he arrives at the perception of the nature of the Church, which leads him to the issue of governance in the Church and its relationships with the Commonwealth.

Soteriological paradigm is determined by the doctrine of grace: R. Hooker asserts that similarly to an essential distinction between the grace of justification (internal, invisible) and the grace of sanctification (external, "visible" through good works), which represents the grace of the one true God, there is a difference between the Church as "body mystical" and "visible Church" although these form the One Church of Christ ${ }^{19}$ :

(1) "The Church mystical" consists of everyone who has been saved by Christ (LEP III, i:2).

(2) "The Church visible" consists of all baptized people, who accepted the faith of Christ (LEP III, i:3-4). Hooker points out that "the Church visible" is, in a sense, "wider" than "The Church mystical" (LEP III, i:8). The relationship between Christ and the Church R. Hooker describes as "inherent copulation" (LEP V, lvi:1) and "mystical conjunction" (LEP V, lvi:7). Drawing an analogy with the Incarnation, he follows Chalcedonian theology while describing mutual participation between God and human beings:

The very cause of his taking upon him our nature was to change it, to better the quality... although in no sort to abolish the substance which he took, nor to infuse into it the natural forces and properties of his Deity (LEP V, liv:5).

Such unity between God and Church, according to Hooker, enables people to enter into «the participation of divine Nature», (LEP V, lvi:7), which leads to a sort of theosis:

Finally, sith God hath deified our nature, though not by turning in into himself, yet by making it his own inseparable habitation, we cannot now conceive how God should without man either exercise divine power, or receive the glory of divine praise. For man is in both an associate of Deity (LEP V, liv:5).

Then R. Hooker moves on to deal with the issue which is directly associated with grace and the nature of the Church, namely, to Sacraments. Sacraments, as stated by R. Hooker, are of mixed nature (LEP V, lvii:2) and:

...their chiefest force and virtue consisteth... in that they are heavenly ceremonies, which God hath sanctified and ordained to be administered in his Church, first, as marks whereby to know when God doth impart the vital or saving grace of Christ unto all that are capable thereof, and secondly as means conditional which God requireth in them unto whom he imparteth grace (LEP V, lvii:3).

They also serve as

... bonds of obedience to God, strict obligations to the mutual exercise of Christian charity, provocations to godliness, preservations from sin, memorials of the principal benefits of Christ... and sacraments are marks of distinction to separate God's own from strangers (LEP V, lvii:2).

19 The references to the text "Of the Laws of Ecclesiastical Polity" include a conventional abbreviation LEP and references to the book, section and paragraph of the classic academic publication edited by J. Keeble: Works of that Learned and Judicious Divine Mr. Richard Hooker with an Account of His Life and Death by Isaac Walton. Arranged by the Rev. John Keble MA. $7^{\text {th }}$ ed. revised by the Very Rev. R. W. Church and the Rev. F. Paget. In 3 vols. Vol. I. Oxford, 1888. 
That is why, listing the main duties of the Church he mentions administering Sacraments together with preaching the Gospel and the liturgy (LEP VII, xviii:5). Clergy and mostly bishops are entrusted with performing these duties:

Requisite therefore it is, that ecclesiastical persons have authority in such things, which kind of authority maketh them that have it prelates (LEP VII, xviii:5).

Addressing the issue of episcopal polity, R. Hooker obviously departs from "Elizabethan conformism". He points out the universal character of episcopal polity even in the first centuries of Christianity:

Nor was this order peculiar unto some few churches, but the whole world universally became subject thereunto; insomuch as they did not account it to be a church which was not subject unto a bishop. It was the general received persuasion of the ancient Christian world, that Ecclesia est in Episcopo, "the outward being of a church consisteth in the having of a bishop" (LEP VII, v:2).

He indicates that the Twelve Apostles were the first bishops. (LEP VII, 4:1).Therefore, he considers it is natural to suppose that subsequent bishops are their successors (to confirm his statement he refers to evidence by Saint Irenaeus, Ignatius of Antioch and Hieronymus):

For in process of time the Apostles gave episcopal authority, and that to continue always with them which had it... The Apostles therefore were the first which had such authority, and all others who have it after them in orderly sort are their lawful successors... For to succed them, is after them to have that episcopal kind of power which was first given to them. "All bishops are," saith Jerome, "the Apostles' successors" (LEP VII, 4:3).

He admits that there was a stage in the history of the Church with Presbyterian governance of local churches, which sparked conflicts in some places: "emulations, strifes, and contentions". Episcopacy, as Hooker maintains, was the remedy necessary to resort to (LEP VII, 5:2).

Here Hooker draws attention to Hieronymus's commentaries to "The Epistle to Titus":

As therefore presbyters do know that the custom of the Church makes them subject to the Bishop which is set over them; so let bishops know that custom, rather than the truth of any ordinance of the Lord's maketh them greater than the rest, and that with common advice they ought to govern the Church (LEP VII, v:8).

Hooker emphasizes that the Church has power by universal consent to change its structure should "urgent cause" arise: he clarifies the nature of such cause mentioning cases of "proud, tyrannical, and unreformable dealings of her bishops" (LEP VII, v:8). R. Hooker's use of the term "universal consent" is of special interest here, and will be crucial for further arguments about secular authority.

R. Hooker is faced with the question of power in the Church and the theme of Royal Supremacy unavoidably associated with it. He points to the distinction between the Church and commonwealth, perceived as "body politick", which is used by the opponents of Royal Supremacy:

In their opinion the church and the commonwealth are corporations, not distinguished only in nature and definition, but in subsistence perpetually severed; so that they which are of the one can neither appoint nor execute, in whole nor in part, the duties which belong unto them which are of the other, without open breach of the law of God, which hath divided them... ( LEP VIII, i:2). 
Objecting to this concept, R. Hooker asserts: "a church and a commonwealth... are things in nature the one distinguished from the other" (LEP VIII, i:2), but although there is a difference between them, it is accidental (LEP VIII, i:5). According to him, the Church constitutes a "society politic" and a "body politic", which exercises true religion. Hooker notes that there are many political societies with religions but the only one, properly called "the Church" practises the religion which is indeed true:

Truth of religion is that proper difference whereby a church is distinguished from other politic societies of men (LEP VIII, i:2).

As a consequence, these are R. Hooker's conclusions:

- To begin with, any political society which practices Christian truth is called the Church;

- Moreover, the Church of Jesus Christ is of two dimensions: as a politic society it has religion whereas as a church it exercises religion revealed by Jesus Christ himself. (LEP VIII, 1:2).

The name " $a$ church", as stated by R. Hooker, denotes such a community of people who:

- are unified by a certain form of regiment;

- differ from others in that they practice Christian religion (LEP VIII, 1:2).

Furthermore, basing on Aristotle, R. Hooker puts forward two more arguments against such distinction: the first one, which will be further elaborated on, is derived from the common good; the second one, which will be addressed later, stems from the perceptions of "the relationship" between the King and the law. As far as the first one is concerned, Hooker writes:

For every politic society that being true which Aristotle hath, namely, "that the scope thereof is not simply to live, nor the duty so much to provide for life, as for means of living well:" and that even as the soul is the worthier part of man, so human societies are much more to care for that which tendeth properly unto the soul's estate, than for such temporal things as this life doth stand in need of... (LEP VIII, i:4).

According to R. Hooker, it's religious issues that are of paramount importance for the welfare of the society and, therefore, public care of ecclesiastical matters is inseparable from other needs connected with the functioning of the state.

Then Hooker defines the terms "church" and "commonwealth": "A commonwealth we name it simply in regard of some regiment or policy under which men live, a Church for the truth of that religion which they profess". (LEP VIII, i:5) In order to describe a possible correlation between the two terms he resorts to a comparison:

As when we name a Schoolmaster and a Physician, these names do not only betoken two accidents, teaching and curing, but also some person or persons in whom these accidents are. For there is no impediment but both may be one man, as well as they are for the most part diverse (LEP VIII, i:5).

Therefore, he maintains, "The commonwealth and the Church therefore being such names, they do not only betoken those accidents of civil government and Christian religion which we have mentioned, but also together with them such multitudes as are the subjects of those accidents" (LEP VIII, i:5).

When we oppose the Church therefore and the commonwealth in a Christian society, we mean by the commonwealth that society with relation unto all the public affairs thereof, only the 
matter of true religion excepted. By the Church, the same society with only reference unto the matter of true religion without any other affairs besides. When that society which is both a Church and a commonwealth doth flourish in those things which belong unto it as a commonwealth, we then say that the commonwealth doth flourish; when in those things which concern it as a Church, the Church doth flourish; when in both, then the Church and commonwealth flourish together (LEP VIII, i:5).

Thus, R. Hooker contends that in a Christian society, unlike a multi-religious one, there is no essential difference between the Church and Commonwealth, which can be exemplified by England, where it is impossible to separate one from the other:

With us therefore the name of a church importeth only a society of men, first united into some public form of regiment, and secondly distinguished from other societies, by the exercise of Christian religion... We hold, that seeing there is not any man of the Church of England, but the same man is also a member of the commonwealth, nor any man a member of the commonwealth, which is not also of the Church of England; therefore as in a figure triangular the base doth differ from the sides thereof, and yet and the selfsame line, is both a base and also a side; a side simply, a base if it chance to be the bottom and underline the rest: so, albeit properties and actions of one kind do cause the name of a commonwealth, qualities and functions of another sort the name of a Church to be given unto a multitude, yet one and selfsame multitude may in such sort be both, and is so with us, that no person appertaining to the one can be denied to be also of the other (LEP VIII, i:2).

That is why he arrives at the conclusion:

The Church and the commonwealth therefore are in this case personally one society, which society being termed a commonwealth as it liveth under whatsoever form of secular law and regiment, a church as it hath the spiritual law of Jesus Christ... (LEP VIII, i:4).

One of the major aspects which caused Presbyterians' attacks against R. Hooker resided in his abovementioned statement that all subjects of the English Crown were Christians practicing the true religion.

Refuting the criticism, R. Hooker responded by a rather broad, inclusive definition:

We here mean true religion in gross, and no according to every particular: for they which in some particular points of religion do swerve from the truth, may nevertheless most truly, if we compare them to men of an heathenish religion, be said to hold and profess that religion which is true (LEP VIII, $\mathrm{i}: 2$ ).

Apparently, this definition is based on Hooker's distinction between visible and invisible Churches, which has already been discussed: those who comprise the former not necessarily belong to the latter.

Having established the correlation between the Church and the state in England, R. Hooker proceeds to the issue of Royal Supremacy. In the beginning he deals with the definition of the term "Dominion" (Its meaning "the power or right of governing or controlling; sovereign authority; lordship, sovereignty; rule, sway" was first recorded around 1430 and was in use until the second half of the $19^{\text {th }}$ century) ${ }^{20}$. The second chapter of the eighth book "Of the Laws of Ecclesiastical Polity" dedicated to this issue opens up with a crucial statement:

${ }^{20}$ Oxford English Dictionary. Online edition. URL: http://www.oed.com/ (accessed 10.05.2017). 
Without order there is no living in public society, because the want thereof is the mother of confusion, whereupon division of necessity followeth, and out of division inevitable destruction (LEP VIII, ii:2).

R. Hooker asserts that "Order can have no place in things, unless it be settled amongst the persons that shall by office be conversant about them" (LEP VIII, ii:2). He expresses a well-known Augustinian argument that all ordered things "are distinguished by degrees. For order is a gradual disposition" (LEP VIII, ii:2), i.e. "order" is perceived as "hierarchy". This hierarchical order lies at the foundation of the world:

The whole world consisting of parts so many, so different, is by this only thing upheld; he which framed them hath set them in order (LEP VIII, ii:2).

According to Hooker, this natural order set by God is characteristic both of nature and society: lower layers are connected with upper layers to comprise together a single whole. (LEP VIII, ii:2). An important role at every level of this hierarchal structure belongs to power $^{21}$, which R. Hooker defines as "ability which we have of ourselves, or receive from others, for performance of any action". (LEP VIII, ii:2). Therefore, he claims that power which is concerned with religion or its aspects is called spiritual. Provided that there is no one who exercises a greater power, such power is termed "dominion, or power supreme" (LEP VIII, ii:2). Then R. Hooker expresses a thought which reflects the central principal of regalism in religion:

When therefore Christian kings are said to have spiritual dominion or supreme power in ecclesiastical affairs and causes, the meaning is, that whithin their own precincts and territories they have authority and power to command even in matters of Christian religion, and that there is no higher nor greater that can in those causes over-command them... their power is termed supremacy, as being the highest, not simply without exception of any thing (LEP VIII, ii:3).

Here it's possible to observe the view on the monarch as the one with supreme jurisdiction, on the one hand, and patrimonial authority, on the other hand. This perception wasn't new to English political and judicial thought: it might have stemmed from the ideas of an Italian jurist Bartolo da Sassoferrato (1313 - 13 July 1357), who had a considerable impact on the English tradition of Roman law ${ }^{22}$.

In view of this context, it should be noted that ideas about the divine origin of the monarchy and, as a consequence, about a divine right of the king to exercise power over all matters in the kingdom, including ecclesiastical aspects, were rooted in the Middle Ages. It should also be taken into account that Hooker was one of the first influential English intellectuals who appreciated the potential of the treatise "De Legibus et Consuetudinibus Angliae" (around 1235) by an English cleric and civil lawyer Henry de Bracton for religious-political constructs. Paradoxically, the text by mediaeval jurist, whose role in English political-judicial thought became crucial in the $17^{\text {th }}$ century, was rather rarely used in the $16^{\text {th }}-17^{\text {th }}$ centuries $^{23}$. (It can be confirmed by a limited number of manuscripts

${ }^{21}$ It is pointed out in OED that the term is synonymous with dominion, meaning control or authority over others; dominion rule; government, command, sway.

22 Palamarchuk A. A. Tsivil'noe pravo v rannestiuartovskoi Anglii: instituty i idei. St. Petersburg, 2015. P. 76-79.

${ }^{23}$ Harvey D.J. The Law Emprynted and Englysshed: The Printed Press as an agent of Change in Law and Legal culture. Oxford; Portland (Oregon), 2015. P. 184. 
of the treatise circulated in England before the first printed edition of $\left.1569^{24}\right)$. The first printed folio carried out by R. Tottel didn't make a difference due to its considerable size and a correspondingly high price.

Up until at least the middle - the second half of the $1580^{\text {th }}$ Bracton's text had been mainly used for practical purposes: as a treatise on legal procedure or on crime law. The significance of Bracton's legacy from a judicial and political perspective most probably was appreciated by W. Cecil ${ }^{25}$, but it was only the publication of "Law Reports" by E.Coke ${ }^{26}$ that made Bracton's text sought-after as an argument in the constitutional dispute ${ }^{27}$. Coke and succeeding English jurists and polemicists viewed Bracton's ideas in terms of the development of secular power (and, primarily, the sphere of the Royal Prerogative) whereas Hooker perceived the constructs of the mediaeval civilists in religious and ecclesiastical context. Well-known theological analogies clarified in Bracton's text the statement borrowed by R. Hooker:

The king has no equal within his realm, [Subjects cannot be the equals of the ruler, because he would thereby lose his rule, since equal can have no authority over equal, or a fortiori a superior, because he would then be subject to those subjected to him. The king must not be under man but under God and under the law, because law makes the king, Let him therefore bestow upon the law what the law bestows upon him, namely, rule and power.] for there is no rex where will rules rather than lex. Since he is the vicar of God, And that he ought to be under the law appears clearly in the analogy of Jesus Christ, whose vicegerent on earth he is, for though many ways were open to Him for his ineffable redemption of the human race, the true mercy of God chose this most powerful way to destroy the devil's work, he would use not the power of force but the reason of justice. Thus he willed himself to be 11under the law that he might redeem those who live under it. For He did not wish to use force but judgment. And in that same way the Blessed Mother of God, the Virgin Mary, Mother of our Lord, who by an extraordinary privilege was above law, nevertheless, in order to show an example of humility, did not refuse to be subjected to established laws. Let the king, therefore, do the same, lest his power remain unbridled. There ought to be no one in his kingdom who surpasses him in the doing of justice ${ }^{28}$.

According to Bracton, there is no analogy between the power of the king and anything else within his realm, and his power can't be belittled or restricted by any means save for voluntary self-restraint, "humility", which, by following the examples of Christ and Mary, makes this authority even more perfect and similar to divine perfection. If law is changeable, the monarch and his will (invariably just) are permanent. As K. J.Nederman precisely comments, "The Bractonian king was a God-fearing and law-abiding man whose unique and characteristic powers rendered him nevertheless insusceptible to correction by his earthy inferiors" 29 .

${ }^{24}$ Henricus de Bracton. De Legibus et Consuetudinibus Angliae. Londini, 1569.

25 Alford S. The Political Creed of William Cecil // The Monarchial Republic of Early Modern England. Essays in Response to Patrick Collinson / ed. by J. F. McDiarmid. London; New York, 2007. P. 79.

${ }^{26}$ Coke E. The Eighth Part of the Reports of Sir Edward Coke, Knt. London, 1727.

${ }^{27}$ English theorists actively referred to Bracton's ideas concerning supreme authority throughout the whole XVII centuries; among his later commentators were Algernon Sidney, John Milton and Thomas Hobbes. Moreover, the text of De Legibus was equally used by both supporters of the royal prerogative and adherers to the notion of parliamentary supremacy.

28 Bracton on the Laws and Customs of England (Bracton de Legibus et Consuetudines Legum Angliae) / ed. and transl. by S. E. Thorne. In 2 vols. Vol. 2. Cambridge (Mass.), 1968. P. 33.

${ }_{29}$ Nederman C. J. Bracton on Kingship Revisited // History of Political Thought. 1984. N 5. P. 63. 
Monarchical power embodied in the sacred and immortal figure thanks to the ability of self-restraint seemed to be more ideal than any institutions and laws except for divine law.

Therefore, when a monarch interfered into a natural process of enacting laws or hearing cases, it didn't represent a situation of the individual (royal will) involvement into the common (law or custom), but signified a descent of something more superior, sacred (royal authority) to something inferior, profane.

It is quite probable that R. Hooker while reading Bracton's treatise, unlike his younger contemporaries, was not so much within an emerging new paradigm, which shaped specific political, judicial and religious spheres, but remained within the context of a mediaeval tradition, which, as B. Tierney pointed out, didn't quite distinguish between religious, moral and positive law, whose boundaries were very vague ${ }^{30}$. It was this perception, which was characteristic of Accursius, to whose texts Bracton resorted to for the basis of his ideas, and Thomas Aquinas. Because of indivisibility of moral and law aspects from a mediaeval scholastic perspective, a monarch was supposed to obey the law, but fulfilling this duty depended only on his free will and not on external force.

These perceptions hadn't lost their relevance in the $16^{\text {th }}-17^{\text {th }}$ centuries. R. Hooker makes it clear:

Sometimes it pleaseth God himself by special appointment to choose out and nominate such as to whom dominion shall be given, which thing he did often in the commonwealth of Israel. They who in this sort receive power have it immediately from God, by mere divine right... By which of these means soever it happen that kings or governors be advance unto their states, we must acknowledge both their lawful choice to be approved of God, and themselves to be God's lieutenants, and confess their power his (LEP VIII, ii:5).

Now it's necessary to remember the second R. Hooker's argument about the distinction between The Church and commonwealth, which he used against Roman-Catholic polemists, on the one hand, and Presbyterian opponents, on the other hand. Referring to Aristotle, he rejects the idea that any king by virtue of his political nature possesses universal (absolute) power, although, as he asserts, a monarch can't be called so unless he has sovereignty over the most essential matters in the state. (LEP VIII, ii:12). At the same time he is confident that the best power for the people is the one which is restricted: by this he means such authority which

is tied unto the soundest, perfectest, and most indifferent rule; which rule is the law... (LEP VIII, ii:12).

Thus, according to R. Hooker, it's the royal authority restricted by law, which is most beneficial for the common good, not the power which is exercised as if the king was the law. (LEP VIII, ii:12) Hooker emphasizes the significance of such governance for common good by quoting one of the Classical Greek treatise, whose author he believed was a Pythagorean Archytas of Tarentum (LEP VIII, ii:12). For the society governed by the king in accordance with the law R. Hooker also puts forward an elegant analogy, concordant with the ideas about harmoniously structured corporate body:

Where the king doth guide the state, and the law the king, that commonwealth is like an harp or melodious instrument, the strings whereof are tuned and handled all by one, following as laws the rules and canons of musical science (LEP VIII, ii:12).

30 Tierney B. Bracton on Government // Speculum. 1963. Vol.38. N 2. P.301. 
By law R. Hooker means not only the law of nature and of God, but also positive law, secular and ecclesiastical, being in harmony with the preceding two (national or municipal law consonant thereunto) (LEP VIII, ii:12).

The last comment will be crucial for further arguments. R. Hooker expresses admiration for

... their wisdom, by whom the foundations of this commonwealth have been laid; wherein though no manner person or cause be unsubject to the king's power, yet so is the power of the king over all and in all limited, that unto all his proceedings the law itself is a rule (LEP VIII, ii:13).

These foundations are reflected in what he calls "the axioms of our regal government", expressed in statements which must have been borrowed by H. Bracton from De Legibus et Consuetudinibus Angliae as it has already been mentioned. They are as follows:

"Attribuat rex legi, quod lex attribuit ei, potestatem et dominium" (LEP VIII, ii :3) ${ }^{31}$.

"Rex non debet esse sub homine, sed sub Deo et lege" (LEP VIII, ii :3) 32 .

"Lex facit regem:" the king's grant of any favour made contrary to the law is void; "Rex nihil potest nisi quod jure potest" (LEP VIII, ii:13) ${ }^{33}$.

Thus, R. Hooker stresses the position of law which serves as the basis for the royal supremacy granting the king sovereign power in all public matters, secular and ecclesiastical, on the one hand, and restricting this same power for the sake of the common good, on the other hand. According to him, it's true for both the state and the church: «It hath been declared already in general, how "the best established dominion is where the law doth most rule the king:" the true effect whereof particularly is found as well in ecclesiastical as in civil affairs... "kings have dominion to exercise in ecclesiastical causes, but according to the laws of the Church». (LEP VIII, ii:17). In keeping with Aristotle, R. Hooker claims that any society is based on two "pillars":

Two foundations there are which bear up public societies; the one, a natural inclination, whereby all men desire sociable life and fellowship; the other, an order expressly or secretly agreed upon touching the manner of their union in living together (LEP I, x:1).

He calls this order (interpreted also as a hierarchy), as it has already been discussed, "the Law of a Commonwealth": "The latter is that which we call the Law of a Commonwealth, the very soul of a politic body, the parts whereof are by law animated, held together, and set on work in such actions, as the common good requireth" (LEP I, x:1). R. Hooker points out that people aspiring for harmonious community in order to protect themselves from their corrupt nature and to establish justice negotiated this order. He emphasizes the principle of "consent", which has already been mentioned, with regards to the structure and governance of the Church. Considering that the Church and the Commonwealth constitute one and the same society, it is hardly surprising that R. Hooker devotes such

31 Cf: "Attribuat igitur rex legi, quod lex attribuit ei, videlicet dominationem et potestatem" (Bracton H. De Legibus et Consuetudinibus Angliae. In 4 vols. Oxford, 1922. P. 33).

32 Cf: "Ipse autem tex non debet esse sub homine sed sub deo et sub lege, quia lex facit regem" (Ibid. P. 33.

${ }^{33} \mathrm{Cf}$, for example: "Nihil enim aliud potest rex in terris, cum sit dei minister et vicarius, nisi id solum quod de iure potest..." (Ibid. P.305). 
careful attention to this principle as far as the royal authority is concerned: to protect their lives, property, and rights which could be violated if everyone set a limit for himself, being biased, people "gave their common consent all to be ordered by some whom they should agree upon" (LEP I, x:4).

Here R. Hooker is in disagreement with Aristotle, according to whom:

....although there be according to the opinion of some very great and judicious men a kind of natural right in the noble, wise, and virtuous, to govern them which are of servile disposition; nevertheless for manifestation of this their right, and men's peaceable contentment on both sides, the assent of them who are to be governed seemeth necessary (LEP I, x:4).

Drawing a comparison with the family of which, according to natural law, the father is its head and master, he remarks that the society being comprised of a large number of families doesn't have such a natural head who would possess the same full and lawful power. The source of such power can be either the consent of the governed or God-given assignment (LEP I, x:4). As every father in his home resembles the king, it doesn't come as a surprise that monarchy was the first form of governance among people. That is why he feels it's justified that those who "of fathers were made rulers..." (LEP I, x:4) retained their title of "Father".

However, the principle of consent is concerned not only with the issue of consent of the governed with the form of governance. It has to do with the laws by which the political society is guided. R. Hooker refers to a conventional distinction: the law of nature has a universally obligatory force whereas the positive law doesn't. "Howbeit laws do not take their constraining force from the quality of such as devise them, but from that power which doth give them the strength of law». (LEP I, x:8) It's established by God that the lawful power for creating laws to govern the political body belongs to the body itself, therefore, every ruler who attempts at exercising this power without a direct command from God or without the consent of the people becomes a tyrant.

Thus, any positive law should be given approval on the part of the governed. It concerns not only with secular laws but also with ecclesiastical laws, which require approbation by the clergy and laity (LEP VIII, vi:8). R. Hooker asserts that this approbation can be carried out by individuals and also through the Parliament (LEP I, x:8). Moreover, the laws which were approved by the society centuries ago remain in effect as the subjects are members of the political body and "corporations are immortal; we were alive in our predecessors, and they in their successors do live still. Laws therefore human, of what kind soever, are available by consent" (LEP I, x:8). Combining together all elements of the system (the king's sovereign right in all secular and ecclesiastical matters received from God and in accordance with the natural law; the law, both secular and ecclesiastical, which restricts this right; the principle of common consent on the part of the subjects with the form of the governance and enacted laws; the corporate nature of the political body which is comprised of inseparable Church and Commonwealth) R. Hooker postulates:

The parliament of England together with the convocation annexed thereunto, is that whereupon the very essence of all government within this kingdom doth depend; it is even the body of the whole realm; it consisteth of the king, and of all that within the land are subject unto him: for they all are there present, either in person or by such as they voluntarily have derived their very personal right unto (LEP VIII, vi:11). 
Then R. Hooker maintains that the Parliament is not "a mere temporal court"34 unable to interfere into ecclesiastical matters. Refuting the converse he refers to the situation during the reign of Mary I Tudor and restored Papal jurisdiction over the English church: if the Queen and Papal legate, Reginald Pole, had considered all laws (including those against the papacy), passed by the Parliament in connection with the ecclesiastical reforms, to be invalid ipso facto, why did they promise and later keep their promises to revoke these same laws in the Parliament? (LEP VIII, vi:11).

Thus, the image of the Parliament (with Convocations annexed to it), which serves as the "Synod" of the reformed English Church, arises. However, it's only in union with the King (King-in-Parliament), who represents the supreme jurisdiction and sovereign (patrimonial) right, that it acquires power over the Church. With regard to this context it should be noted that the sovereign right of the English monarch to take charge of state and ecclesiastical matters originates from the combination of power granted by God and natural law, which is the basis for both common law and civil and canon law. The latter is of particular importance and relevance today as up until now canon law of the reformed English church has been linked with common (or statute) law in Great Britain. It is also worth mentioning that the role of judicial tradition of civil law in shaping the perceptions of the royal supremacy as the combination of the delegated divine power, judicial prerogative and patrimonial authority was fundamental. Up until now this issue has not been properly researched in Russian and, to a certain extent, international historiography.

R. Hooker became one of the first English theologians who actively resorted to jurists' theoretical discourse about law, monarchy, and Church, in particular, to Bartolo and Bracton. R. Hooker and his main work "Of the Laws of Ecclesiastical Polity" had a considerable influence on the English theological-political and political-judicial thought in the $17^{\text {th }}$ century and, as a consequence, on forming, especially at the time after the Restoration, specific orthodoxy and orthopraxy of the Church of England. It is within this orthodoxy that the doctrine of "passive obedience" to the power of the Crown, which was characteristic of both ecclesiastic and political orthodoxy (especially that of the Tories) in the $18^{\text {th }}-$ $19^{\text {th }}$ centuries, was formed. The marginalization of this orthodoxy as well as constitutional changes $\left(18^{\text {th }} \mathrm{c}\right.$.) and a constitutional crisis in the relationship between the Church and the Commonwealth $\left(19^{\text {th }} \mathrm{c}\right.$.) resulted in appreciable changes not only in perceptions of the relationships between the English confessional state and the reformed Church of England but also in the disintegration of the inner unity within the latter, in addition to an acute crisis of self-identity which the church is going through at present.

Nonetheless, the Royal Supremacy remains a major element in the structure lying at the heart of identity of the Church of England. The connections between the English monarch and the English church emerged during the Anglo-Saxon period of the British history and were developed throughout the Middle Ages. They survived a turbulent century of reformations and took new shape and acquired new foundations without having lost the former ones. This mediaeval legacy continues to be a crucial functioning element in the communal existence of the English society, in particular as far as the relationships between the state and the church are concerned and the relationships between churches.

${ }^{34}$ E. Coke also referred to Parliament as the court. Palamarchuk A. A. Tsivil'noe pravo v rannestiuartovskoi Anglii: instituty i idei. P. 69, footnote 116. 


\section{References}

Alford S. The Political Creed of William Cecil. The Monarchial Republic of Early Modern England.

Essays in Response to Patrick Collinson. Ed. by J. F. McDiarmid. London; New York, Routledge Publ., 2007, pp. 75-90.

Avis P. Anglicanism and the Christian Church. London, T\&T Clark Publ., 2002, 393 p.

Clary I. H. Hot Protestants: A Taxonomy of English Puritanism. Puritan Reformed Journal, 2010, no. 2-1, pp. 41-66.

Davydov I. P., Fadeyev I. A. (Etno) Religioznaia identichnost': metodologicheskie aspekty klassifikatsii. Iugra, Sibir', Rossiia: politicheskie, ekonomicheskie, sotsiokul'turnye aspekty proshlogo i nastoiashchego. Nizhnevartovsk, Nizhnevartovsk State University Press, 2016, pp. 12-16. (In Russian)

Fadeyev I. A. Tserkov Anglii: problema konfessional'noi samoidentifikatsii v istoricheskoi perspektive. Moscow, Maska Publ., 2015, 416 p. (In Russian)

Gibbs L. Richard Hooker's Via Media Doctrine of Scripture and Tradition. Harvard Theological Review, 2002, vol. 95 (2), pp. 227-235.

Harvey D. J. The Law Emprynted and Englysshed: The Printed Press as an agent of Change in Law and Legal culture. Oxford; Portland (Oregon), Hart Publishing, 2015, 308 p.

Hurst J.F. The Elizabethan Settlement of the Church of England. The American Journal of Theology, 1899, vol. 3 (4), pp. 679-694.

Lake P. The 'Anglican Moment'? Richard Hooker and the Ideological Watershed of the 1590s. Anglicanism and the Western Christian Tradition. Ed. by Platten S. Norwich, Canterbury Press, 2003, pp. 90-121.

Laski H. J. The Political Ideas of James I. Political Science Quarterly, 1919, vol. 34 (2), pp. 290-304.

Nederman C. J. Bracton on Kingship Revisited. History of Political Thought, 1984, no. 5, pp. 61-77.

Nichols A. The Panther and the Hind. A Theological History of Anglicanism. Edinburgh, T\&T Clark Publ., 1993, $186 \mathrm{p}$.

Palamarchuk A. A. Tsivil'noe pravo v rannestiuartovskoi Anglii: instituty i idei. St. Peterburg, Aleteiia Publ., 2015, 326 p. (In Russian)

Percy M. Opportunity Knocks: Church, Nationhood and Establishment. The Established Church. Ed. by M. Chapman, M. Maltby, W. Whyte. London, T\&T Clark Publ., 2011, pp. 26-38.

Podmore C. Aspects of Anglican Identity. London, Church House Publishing, 2005, 196 p.

Ramsey M. The Anglican Spirit. New York, Seabury Classics Publ., 2004, 147 p.

Tierney B. Bracton on Government. Speculum, 1963, vol. 38, no. 2, pp. 259-317. 